\title{
Türkiye Suları İçin İsparoz Balığı’nın (Diplodus annularis Linnaeus, 1758) Büyüme Özellikleri
}

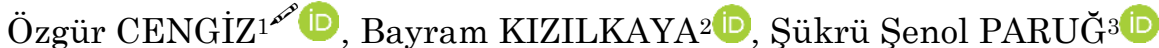

${ }^{1}$ Van Yüzüncü Yıl Üniversitesi, Su Ürünleri Fakültesi, Van, ${ }^{2}$ Çanakkale Onsekiz Mart Üniversitesi, Deniz Bilimleri ve Teknolojisi Fakültesi, Çanakkale, ${ }^{3}$ Kastamonu Üniversitesi, Su Ürünleri Fakültesi, Kastamonu, Türkiye

1https://orcid.org/0000-0003-1863-3482, ${ }^{2}$ https://orcid.org/0000-0002-3916-3734, ${ }^{3}$ https://orcid.org/0000-0002-7991-4651

$\bowtie$ : ozgurcengiz17@gmail.com

\section{ÖZET}

Bu çalışma Ocak 2016-Aralık 2016 tarihleri arasında Saros Körfezi'nde yürütülmüştür. Tüm bireyler için ağırlık-boy ilişkisi $\mathrm{W}=$ $0.0331 \mathrm{TL}^{2.77}$ olarak hesaplanmıştır. Maksimum boya sahip bir adet isparoz balığ $(23.2 \mathrm{~cm}$ toplam boy ve $180.00 \mathrm{gr}$ toplam ağırlık) 25 Ağustos 2016 tarihinde balıkçılar tarafından İbrice Limanı (Saros Körfezi) açıklarında olta ile yakalanmıştır. Bu çalışmanın amacı türün Türkiye suları için maksimum boy kaydını sunmaktır.
Araştırma Makalesi

Makale Tarihçesi

Geliş Tarihi : 12.02 .2019

Kabul Tarihi : 09.05.2019

Anahtar Kelimeler

Diplodus annularis

İsparoz

Büyüme özellikleri

Maksimum boy

Ağırlık-boy ilişkisi

Saros Bay

\section{Growth Characteristics of Annular Seabream (Diplodus annularis Linnaeus, 1758) for Turkish Waters}

\begin{abstract}
This study was conducted between January 2016 and December 2016 in Saros Bay. The weight-length relationship was calculated as $\mathrm{W}=$ $0.0331 \mathrm{TL}^{2.77}$ for all samples. A single specimen of $D$. annularis with the maximum size $(23.2 \mathrm{~cm}$ in total length and $180.00 \mathrm{~g}$ in total weight) was caught off İbrice Bight (Saros Bay) with handline by fisherman on 25 August 2016. The aim of this study was to present the maximum size record of the related species for the Turkish Waters.
\end{abstract}

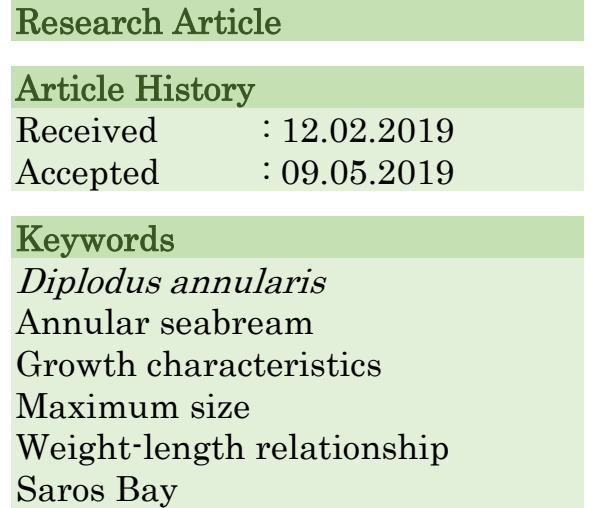

To Cite : Cengiz Ö, Kızılkaya B, Paruğ ŞŞ 2019. Türkiye Suları İçin İsparoz Balığı'nın (Diplodus annularis Linnaeus, 1758) Büyüme Özellikleri. KSÜ Tarım ve Doğa Derg 22(5): 817-822. DOI: 10.18016/ksutarimdoga.vi.525929.

\section{GİİŞ}

Maksimum boy ve ağırlık değerleri, balıkçılık yönetimi açısından oldukça önemli parametrelerdir (Dulčić ve Soldo, 2005). Bu parametreler, doğrudan ya da dolaylı olarak, stok tayini çalışmalarının çoğunda kullanıldıkları için, bilhassa, ticari olarak sömürülen balık türlerinde maksimum boy ve ağırlık değerlerinin güncellenmesi her geçen gün önem kazanmaktadır (Borges, 2001; Cengiz, 2014).

Bununla beraber, balıkçılık yönetiminde sıklıkla kullanılan diğer bir parametre ise ağırlık-boy ilişkisidir (Erzini, 1994). Bu sebepten dolayı, dünyanın farklı bölgelerindeki balık türlerinin ağırlık-boy ilişkisine değinen yayınların sayısında bir artış söz konusudur (Froese ve ark., 2011). Ağırlık-boy ilişkisi (a) farklı habitatlardan ve/veya bölgelerden yakalanan balık türlerinin yaşam döngülerini ve morfolojilerini kıyaslamaya (Gonçalves ve ark., 1997; Moutopoulos ve Stergiou, 2002), (b) balık türlerinin büyümesindeki mevsimsel değişiklikleri ve kondisyon indekslerini izlemeye (Safran, 1992; Richter ve ark., 2000), (c) bir balık populasyonunun biyokütlesini hesaplamaya (Petrakis ve Stergiou, 1995; Dulčić ve Kraljević, 1996) olanak sağlamaktadır. $\mathrm{Bu}$ ilişkiler çalışma bölgesindeki çevresel şartlara ve örnekleme zamanına bağlı olarak değişebileceğinden dolayı (Torres ve ark., 2012) ağırlık-boy ilişkisine yönelik çalışmalar balık populasyonları için düzenli aralıklarla güncellenmelidir (İşmen ve ark., 2007; Özekinci ve ark., 2009).

Sparidae familyası üyesi olan isparoz balığı (Diplodus annularis Linnaeus, 1758) Atlas Okyanusu'nun doğusundan Karadeniz kıyılarına kadar geniş bir bölgede, yüzeyden itibaren 90 m'ye kadar olan derinliklerde dağılım gösteren ve çoğunlukla Posidonia yataklarında ve kumlu dip yapısına sahip yerlerde yaşayan, karnivor bir balık türüdür (Froese ve Pauly, 2018). 
Türkiye'de, balık türlerinin maksimum boy ve ağırlık değerlerine yönelik kanıtlanabilir çalışmalar son derece yenidir. Kısaca özetlemek gerekirse, şu ana kadar bu araştırmalar barbun (Mullus barbatus Linnaeus, 1758) (Filiz, 2011), lüfer (Pomatomus saltatrix Linnaeus, 1766) (Cengiz, 2014), gelincik (Phycis phycis Linnaeus, 1766) (Filiz ve Sevingel, 2014), papağan (Sparisoma cretense Linnaeus, 1758) (Filiz ve Sevingel, 2015), kırlangıç (Chelidonichthys lucerna Linnaeus, 1758) (Hasimoğlu ve ark., 2016), çipura (Sparus aurata Linnaeus, 1758 (Aydın, 2018), dil (Solea solea Linnaeus, 1758) (Cengiz, 2018a), iskatari (Spondyliosoma cantharus Linnaeus, 1758) (Cengiz, 2018b) ve zargana (Belone belone Linnaeus. 1761) (Acarli ve ark., 2018) balıkları üzerine yürütülmüştür. Bu çalışma isparoz balığının ağırlıkboy ilişkisini güncellemekle beraber Türkiye suları için türün maksimum boy kaydını sunuyor.

\section{MATERYAL ve YÖNTEM}

Ege Denizi'nin kuzeyinde yer alan Saroz Körfezi, güneyde Gelibolu Yarımadası ile kuzeyde Trakya kıyıları arasında bulunan ve yaklaşık olarak $60 \mathrm{~km}$ kadar içeri sokulan üçgen şeklinde bir körfezdir (Tokat ve Sayın, 2007). 2000 yılından beri trol avcılığına kapalı olan körfez (Cengiz ve ark., 2011) 22.12.2010 tarihinde Özel Çevre Koruma bölgesi olarak ilan edilmiştir. Balık örnekleri bölgede Ocak 2016 - Aralık 2016 döneminde balıkçılar yardımıyla 0-30 m arası derinliklerde oltalar ile yakalanmıştır. Örneklerin boyları $\pm 1 \mathrm{~mm}$, vücut ağırlıkları $\pm 0.01 \mathrm{gr}$ hassasiyette ölçülmüştür.

Maksimum boya sahip birey, 25 Ağustos 2016 tarihinde İbrice Limanı (Saros Körfezi) açıklarında elde edilmiş. Mater ve ark. (2009) göre tanımlanmış ve bilimsel ismi FishBase'de (Froese ve Pauly, 2018) kontrol edilmiştir. Gıda Tarım ve Hayvancılık Bakanlığı'nın 4/1 Numaralı Ticari Amaçlı Su Ürünleri Avcılığının Düzenlenmesi Hakkında Tebliğ (No: 2016/35)'de toplam boy "ağız kapalı iken balık başının ön ucu ile kuyruk yüzgecinin en uzun ışınının bitim noktası arasındaki izdüşüm uzunluğu" şeklinde ifade edilir.

Türün ağırlık-boy ilişkisi Ricker (1975) tarafından önerilen $W=a L^{b}$ denklemi kullanılmak suretiyle tüm bireyler için hesaplanmıştır. Bu denklemde $W$, gram cinsinden balığın toplam ağırlığı; $L$, toplam boy $(\mathrm{cm}) ; a$ ve $b$ büyümeyi ifade eden sabitlerdir. Ĕğer $b$ değeri 3 'ten büyük ise tür pozitif allometrik büyüme, 3'den küçük ise negatif allometrik büyüme, 3’e eşit ise izometrik büyüme göstermektedir (Bagenel ve Tesch, 1978). $a$ ve $b$ parametrelerinin sonuçlarına t-testi uygulamak suretiyle $b$ değerinin izometrik büyümeden $(b=3)$ farklı olup olmadığ ve farklı ise büyümenin pozitif veya negatif olduğuna karar verilmiştir (Avşar, 2005).

\section{BULGULAR}

Bir ylllık çalışma sonunda toplam 159 birey örneklenmiştir. Maksimum boy ve ağırlığa sahip bir adet isparoz balığ $(23.2 \mathrm{~cm}$ toplam boy ve $180.00 \mathrm{gr}$ toplam ağırlık) (Şekil 1) 25 Ağustos 2016 tarihinde balıkçılar tarafından İbrice Limanı (Saros Körfezi) açıklarında (Şekil 2) olta ile yakalanmıştır.

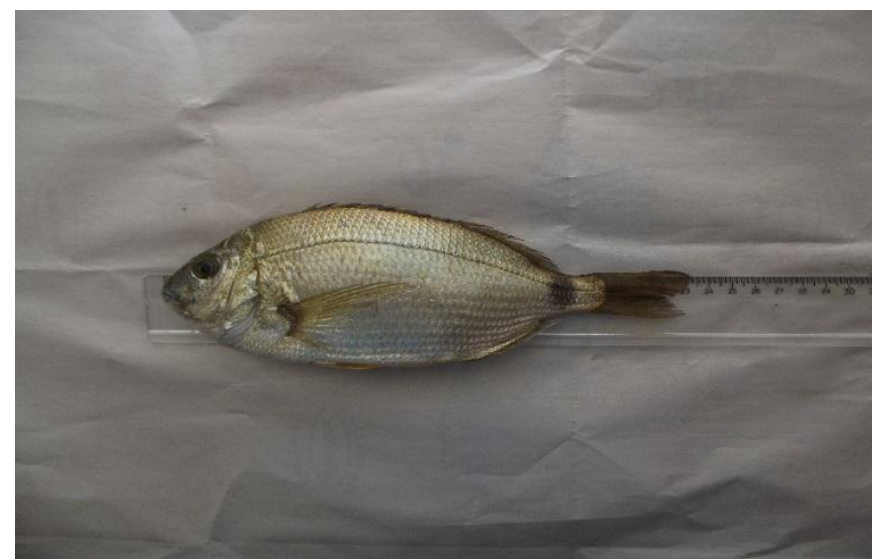

Şekil 1. $23.2 \mathrm{~cm}$ toplam boya ve 180.00 gr ağırlığa sahip isparoz balığı.

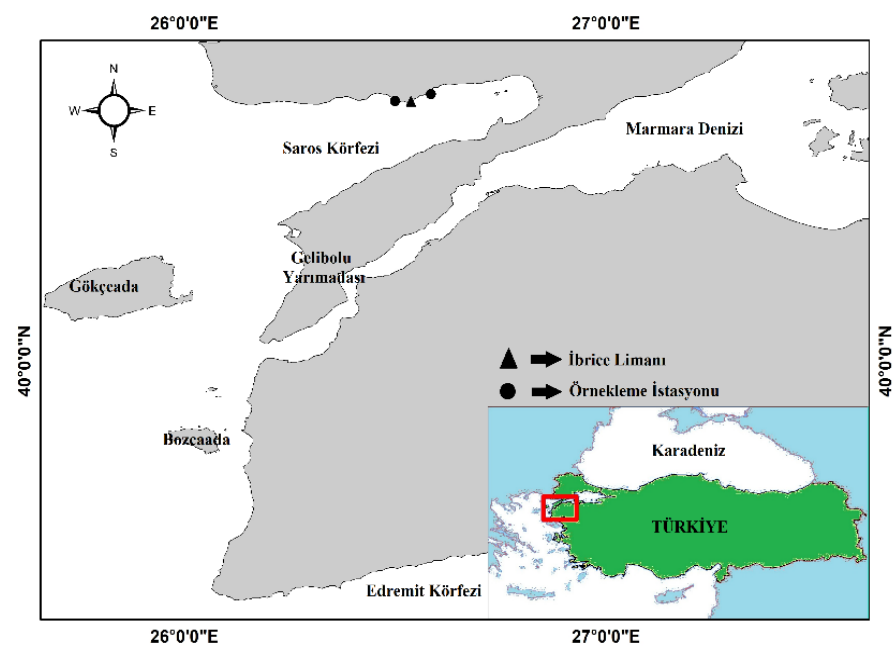

Şekil 2. Örnekleme istasyonu.

Yakalanan balıkların minimum ve maksimum boy ve ağırlık değerleri, sırasıyla, $12.0 \mathrm{~cm}(28.69 \mathrm{gr})$ ve 23.2 cm (180.00 gr)'dir. Bireylerin ortalama boyu ve ağırlığ $14.4 \pm 2.42 \mathrm{~cm}$ ve $54.59 \pm 23.67 \mathrm{gr}$ olarak bulunmuştur. Tüm bireyler için ağırlık-boy ilişkisi $\mathrm{W}=0.0331 \mathrm{TL}^{2.77}$ olarak hesaplanmıştır. İsparoz balığının negatif allometrik büyüme gösterdiği saptanmıştır (Şekil 3).

Türkiye suları için isparoz balığının boy ve ağırlık değerlerinin karşılaştırılması ise Çizelge 1'de gösterilmektedir.

\section{TARTIŞMA ve SONUÇ}

İsparoz balığının dünyada maksimum boyu $27.5 \mathrm{~cm}$ 'dir (Froese ve Pauly, 2018). Bilindiği üzere, aşırı avcılığa maruz kalan türlerin boyları zaman içersinde gitgide 
küçülmektedir. Eğer bir birey hiçbir av baskısına maruz kalmazsa. maksimum boya ulaşabilir (Filiz, 2011; Cengiz, 2018a). İlave olarak, balıkların beslenme faaliyetleri ve buna bağlı olarak ortamdaki besin bolluğu, sıcaklık, oksijen, tuzluluk, kirlilik gibi parametre değerleri, predatörlerin varlığ ve türler arasındaki av-avcı ilişkisinin rolü bu çeşit boya ulaşmayı etkileyen diğer önemli unsurlardır (Helfman ve ark., 2009; Acarli ve ark., 2018). Bu yorumlardan yola çıkılarak maksimum boy ve ağırlık değerlerinde görülen bölgesel farklılıkların aşırı av baskısına ve çevresel şartlara bağlı olduğu sonucu ortaya çıkmaktadır.

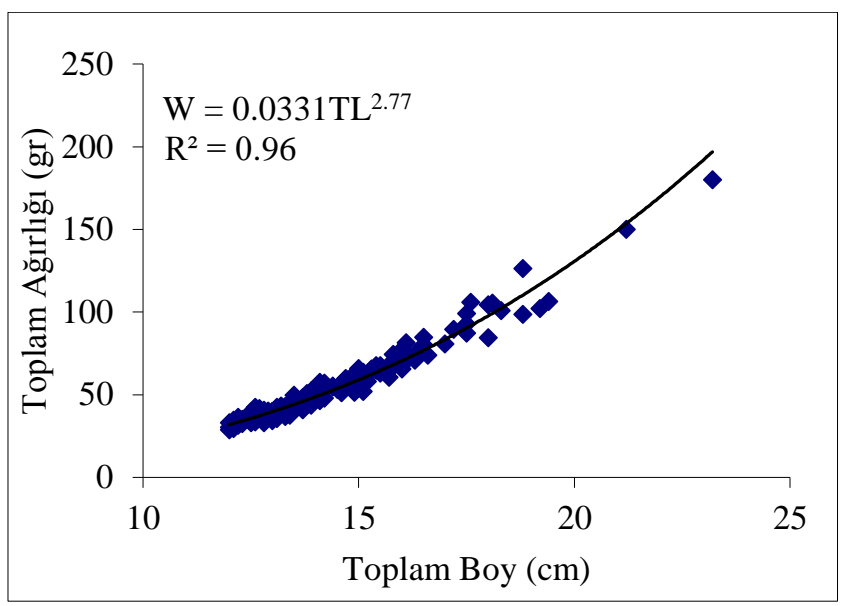

Şekil 3. İsparoz balığının ağırlık-boy ilişkisi

Çizelge 1. Türkiye suları için isparoz balığının boy ve ağırlık değerlerinin karşılaştırılması

\begin{tabular}{|c|c|c|c|c|c|c|}
\hline Yazar(lar) & Bölge & $\mathrm{N}$ & $L_{\text {min }}-L_{\text {mak }}(\mathrm{cm})$ & $\mathrm{W}_{\min }-\mathrm{W}_{\mathrm{mak}}(\mathrm{gr})$ & $\mathbf{a}$ & $\mathrm{b}$ \\
\hline Tosunoğlu ve ark. (1997) & İzmir Körfezi & 205 & $6.5-15.0$ & $6.00-79.00$ & 0.0210 & 3.02 \\
\hline Kınacıgil ve Akyol (2001) & İzmir Körfezi & 160 & $7.8-15.6$ & $9.00-100.00$ & 0.0140 & 3.19 \\
\hline Çiçek ve ark. (2006) & Babadil Limanı & 89 & $7.9-16.7$ & $7.37-78.86$ & 0.0113 & 3.14 \\
\hline Karakulak ve ark. (2006) & Gökçeada & 372 & $7.7-17.7$ & - & 0.0068 & 3.31 \\
\hline Özaydın ve Taşkavak (2006) & İzmir Körfezi & 929 & $7.9-16.8$ & $11.21-102.00$ & 0.0245 & 2.97 \\
\hline Akyol ve ark. (2007) & Gökova Körfezi & 159 & $9.5-19.0$ & $15.80-105.10$ & 0.0179 & 2.98 \\
\hline Gökçe ve ark. (2007) & Kuzey Ege & 718 & $8.3-20.8$ & $8.00-142.00$ & 0.0177 & 2.99 \\
\hline İşmen ve ark. (2007) & Saros Körfezi & 108 & $8.8-15.6$ & $9.00-70.00$ & 0.0160 & 3.01 \\
\hline Özaydın ve ark. (2007) & İzmir Körfezi & 2517 & $5.1-16.1$ & - & 0.0190 & 3.04 \\
\hline Sangun ve ark. (2007) & Kuzey Doğu Akdeniz & 154 & $10.3-15.0$ & $14.4-51.45$ & 0.0370 & 2.67 \\
\hline Çakır ve ark. (2008) & Edremit Körfezi & 887 & $7.3-13.8$ & $8.66-72.13$ & 0.00005 & 2.82 \\
\hline İlkyaz ve ark. (2008) & İzmir Körfezi & 1443 & $7.8-18.3$ & - & 0.0123 & 3.13 \\
\hline Acarli ve ark. (2009) & Homa Dalyanı & 7 & $10.4-13.2$ & $19.08-43.94$ & 0.0085 & 3.31 \\
\hline Gökçe ve ark. (2010) & İskenderun Körfezi & 33 & $12.2-15.0$ & $26.88-51.82$ & 0.0173 & 2.97 \\
\hline Gürkan ve ark. (2010) & Çandarlı Körfezi & 25 & $3.9-13.5$ & $0.72-41.56$ & 0.0085 & 3.28 \\
\hline Keskin ve Gaygusuz (2010) & Erdek Körfezi & 7 & $3.6-16.9$ & - & 0.0134 & 3.11 \\
\hline Bök ve ark. (2011) & Marmara Denizi & 15 & $7.0-16.7$ & - & 0.0220 & 2.95 \\
\hline Demirel ve Dalkara (2012) & Marmara Denizi & 81 & $10.0-16.7$ & - & 0.0040 & 3.43 \\
\hline Cengiz (2013) & Gelibolu Yarımadası & 282 & $8.7-19.4$ & $10.63-126.22$ & 0.0153 & 3.05 \\
\hline Acarli ve ark. (2014) & Homa Dalyanı & 121 & $3.9-15.5$ & $0.90-68.00$ & 0.0100 & 3.19 \\
\hline Bilge ve ark. (2014) & Güney Ege & 2554 & $5.3-16.3$ & - & 0.0192 & 3.04 \\
\hline Kasapoğlu ve Düzgüneş (2014) & Karadeniz & 6 & $6.4-7.8$ & $2.79-8.21$ & & - \\
\hline Altın ve ark. (2015) & Gökçeada & 923 & $1.1-14.0$ & $0.01-48.33$ & 0.0110 & 3.10 \\
\hline Kara ve ark. (2017) & Gediz Deltası & 91 & $8.0-15.5$ & $7.70-66.50$ & 0.0085 & 3.24 \\
\hline Bu çalışma & Saros Körfezi & 159 & $12.0-23.2$ & $28.69-180.00$ & 0.0331 & 2.77 \\
\hline
\end{tabular}

Özaydın ve ark. (2000), İşmen ve ark. (2007), İlkyaz ve ark. (2010), Kapiris ve Klaoudaos (2011) ve Cengiz (2013) farklı balık türleri üzerinde yaptıkları çalışmalarda boy ve ağırlık aralıklarını etkileyen faktörlerin örnekleme yöntemi ve zamanı, bölgeler arasında görülen sıcaklık varyasyonları, beslenme faaliyetleri, örneklemede kullanılan farklı av araçları ve bu av araçlarının seçicilik özellikleri olduğunu belirtmişlerdir. Benzer şekilde, ağırlık-boy ilişkisi balıkların cinsiyetine, gonad gelişimine, çevresel faktörlerdeki yıllık değişimlere, mevsimsel farklılıklara ve türlerin korunmasına yönelik alınan önlemlere (Dulčić ve Kraljević, 1996; Wootton, 1998; Froese, 2006; Verdiell-Cubedo ve ark., 2006), yakalanan birey sayısına ve bireylerin boy ve ağırlık aralıklarına (Moutopoulos ve Stergiou, 2002) bağlıdır. Çizelge 1'e bakıldığında bu çalışma ile önceki çalışmalar arasında boy ve ağırlık aralıklarında ve ağırlık-boy ilişkilerinde görülün farklılıklar yukarıda bahsedilen bir veya birden fazla etmenle açıklanabilir. Sonuç olarak, balık stoklarıyla ilgili yapılacak çalışmalardan daha sağlıklı sonuçlar alınabilmesi için böylesi kanıtlanabilir araştırmaların, mümkünse eğer, ağırlık-boy ilişkileri ile beraber her balık türü için ayrı ayrı gerçekleştirilmesi ve belli zaman dilimleri içerisinde güncellenmesi önem arz etmektedir. Böylelikle bu bilgiler ışığında elde edilecek bulgular, stok ile ilgili mevcut durumu daha net ortaya 
koyabilir. $\mathrm{Bu}$ durum ise, balıkçılık yönetiminde planlanan stratejilerin daha sağlam temeller üzerinde inşa edilmesine olanak sağlar. Bu açıdan bakıldığında, dünyada da her geçen gün sayısı artan böylesi kanıtlanabilir araştırmaların (Borges, 2001; Dulčić ve Soldo, 2005, 2006; Agüero ve ark., 2010; Hossain, 2010; Navarro ve ark., 2012; Hossain ve ark., 2017) Türkiye'de de desteklenmesi sürdürülebilir bir balıkçılık anlayışı için son derece hayati önem taşımaktadır.

\section{TEŞEKKÜR}

Yazarlar yardımlarından dolayı balıkçı Engin Tunç'a ve öğretim görevlisi Semih Kale’ye teşekkür ediyor.

\section{KAYNAKLAR}

Acarli D, Kara A, Bayhan B, Çoker T 2009. Catch Composition and Catch Efficiency of Species Caught from Homa Lagoon (Izmir Bay, Aegean Sea). Ege Journal of Fisheries and Aquatic Sciences, 26: 39-47.

Acarli D, Kara A, Bayhan B 2014. Length-Weight Relations for 29 Fish Species from Homa Lagoon, Aegean Sea, Turkey. Acta Ichthyologica et Piscatoria, 44: 249-257.

Acarli D, Kale S, Çakır K 2018. A New Maximum Length for the Garfish. Belone belone (Linnaeus, 1761) in the Coast of Gökçeada Island (Aegean Sea. Turkey). Cahiers de Biologie Marine, 59: 385-389.

Agüreo JDLC, Gomez VMC, Navarro JTN 2010. New Maximum Size Record for the Chili Sea Catfish Notarius troschelii (Siluriformes: Ariidae) from the Tropical Eastern Pacific. Marine Biodiversity Record, 3: e107.

Akyol O, Kınacıgil HT, Şevik R 2007. Longline fishery and length-weight relationships for selected fish species in Gökova Bay (Aegean Sea, Turkey). International Journal of Natural and Engineering Sciences, 1: 1-4.

Altın A, Ayyıldız H, Kale S, Alver C 2015. LengthWeight Relationships of 49 Fish Species From Shallow Waters of Gökçeada Island, Northern Aegean Sea. Turkish Journal of Zoology, 39: 1-5.

Avşar D 2005. Balıkçılık Biyolojisi ve Populasyon Dinamiği. Nobel Kitabevi. Adana.

Aydin M 2018. Maximum Length and Age Report of Sparus aurata (Linnaeus, 1758) in the Black Sea. Journal of Applied Ichthyology, 00: 1-3.

Bagenal TB, Tesch FW 1978. Age and growth. In: Methods for assessment of fish production in fresh waters. (T.B. Bagenal ed). 3rd edition. IBP Handbook No. 3. Blackwell Science Publications. Oxford: 101-136.

Bilge G, Yapıcı S, Filiz H, Cerim H 2014. WeightLength Relations for 103 Fish Species from the Southern Aegean Sea. Turkey. Acta Ichthyologica et Piscatoria, 44: 263-269.
Borges L 2001. A New Maximum Length for the Snipefish Macrohamphosus scolopax. Cybium, 25: 191-192.

Bök DT, Göktürk D, Kahraman AE, Alıclı TZ, Acun T, Ateş C 2011. Length-Weight Relationships of 34 Fish Species from the Sea of Marmara, Turkey. Journal of Animal and Veterinary Advances, 10: 3037-3042.

Cengiz Ö, İşmen A, Özekinci U, Öztekin A 2011. Saroz Körfezi (Kuzey Ege Denizi) Balık Faunası Üzerine Bir Araştırma. Afyon Kocatepe Üniversitesi Fen Bilimleri Dergisi, 11: 31-37.

Cengiz Ö 2013. Length-Weight Relationships of 22 Fish Species from the Gallipoli Peninsula and Dardanelles (northeastern Mediterranean. Turkey). Turkish Journal of Zoology, 37: 419-422.

Cengiz Ö 2014. A New Maximum Length Record of the Bluefish (Pomatomus saltatrix Linnaeus, 1766) for Turkey Seas. Bitlis Eren Üniversitesi Fen Bilimleri Dergisi, 3: 113-116.

Cengiz Ö 2018a. Weight-Length Relationship with Maximum Size Record of the Common Sole (Solea solea Linnaeus, 1758) in the Aegean Sea. Gece Kitaplığı Yayınevi, Birinci Baskı, Aralık 2018. Ankara. Türkiye. 7-17 s.

Cengiz Ö 2018b. Türkiye Denizleri İçin İskatari Balığı'nın (Spondyliosoma cantharus Linnaeus, 1758) Maksimum Boy Kaydı. International Eurasian Conference on Biological and Chemical Sciences. 26-27April 2018. Ankara. Turkey.

Çakır DT, Koç HT, Başusta A, Başusta N 2008. Length-Weight Relationships of 24 Fish Species From Edremit Bay Aegean Sea. e-Journal of New World Sciences Academy Natural and Applied Sciences, 3(1):47-51.

Çicek E, Avsar D, Yeldan H, Özütok M 2006. LengthWeight Relationships for 31 Teleost Fishes Caught by Bottom Trawl Net in the Babadillimani Bight (northeastern Mediterranean). Journal of Applied Ichthyology, 22: 290-292.

Demirel N, Dalkara ME 2012. Weight-Length Relationships of 28 Fish Species in the Sea of Marmara. Turkish Journal of Zoology, 36: 785-791.

Dulčić J, Kraljević M 1996. Weight-Length Relationships for 40 fish species in the Eastern Adriatic (Croatian waters). Fisheries Research, 28: 243-251.

Dulčić J, Soldo A 2005. A New Maximum Length for the Grey Triggerfish. Balistes capriscus Gmelin, 1789 (Pisces: Balistidae) from the Adriatic Sea. Institute of Oceanography and Fisheries-Split Croatia, 88: 1-7.

Dulčić J, Soldo A 2006. A New Maximum Length for the Garpike Belone belone (Belonidae). Cybium, 30: 382 .

Erzini K 1994. An Empirical Study of Variability in Length at Age of Marine Fishes. Journal of Applied Ichthyology, 10: 17-41. 
Filiz H 2011. A New Maximum Length for the Red Mullet, Mullus barbatus Linnaeus. 1758. Biyoloji Bilimleri Araştırma Dergisi, 4: 131-135.

Filiz H, Sevingel N 2014. A New Maximum Length for the Forkbeard, Phycis phycis (Linnaeus, 1766) in the Mediterranean Sea. Karadeniz Fen Bilimleri Dergisi, 4: 43-48.

Filiz H, Sevingel N 2015. A New Maximum Length for the Parrotfish, Sparisoma cretense (Linnaeus, 1758) in the Mediterranean Sea. Journal of Aquaculture Engineering and Fisheries Research, 1: $140-143$.

Froese R 2006. Cubelaw. Condition Factor and WeightLength Relationships: History. Meta-analysis and Recommendations. Journal of Applied Ichthyology. 22: 241-253.

Froese R, Tsikliras AC, Stergiou KI 2011. Editorial Note on Weight-Length Relations of Fishes. Acta Ichthyologica et Piscatoria, 41: 261-263.

Froese R, Pauly D (Eds) 2018. FishBase. World Wide Web Electronic Publication. http://www.fishbase. org/summary/1752 (Erişim tarihi: 11.02.2019).

Gonçalves JMS, Bentes L, Lino PG, Ribeiro J, Canário AVM, Erzini K 1997. Weight-Length Relationships for Selected Fish Species of the Small-Scale Demersal Fisheries of the South and Southwest Coast of Portugal. Fisheries Research, 30: 253-256.

Gökçe G, Aydın İ, Metin C 2007. Length-Weight Relationships of 7 Fish Species from the North Aegean Sea, Turkey. International Journal of Natural and Engineering Sciences, 1: 51-52.

Gökçe G, Mustafa C, Filiz H 2010. Length-Weight Relationship of Marine Fishes off Yumurtalik Coast (Iskenderun Bay), Turkey. Turkish Journal of Zoology, 34: 101-104.

Gürkan Ş, Bayhan B, Akcınar SC, Taskavak E 2010. Length-Weight Relationship of Fish from Shallow Waters of Candarli Bay (North Aegean Sea, Turkey). Pakistan Journal of Zoology, 42: 495-498.

Hasimoğlu A, Ak O, Kasapoğlu N, Atılgan E 2016. New Maximum Length Report of Chelidonichthys lucerna (Linneaus, 1758) in the Black Sea. Turkey. Journal of the Black Sea / Mediterranean Environment, 22: 149-154.

Helfman GS, Collatte BB, Facey DE, Bowen BW 2009. The Diversity of Fishes: Biology. Evolution and Ecology. 2nd edn. Wiley-Blackwell. UK. 720 p.

Hossain MY 2010. New Maximum Size Record for the Goonch Bagarius yarrelli (Sykes, 1839) (Siluriformes: Sisoridae) from the Ganges River. Sains Malaysiana, 39: 157-159.

Hossain MY, Hossen MA, Nawer F, Khatun D, Pramanik MNU, Parvin MF, Yahya K 2017. New Maximum Size Records and Length-Weight Relationships for Two Species. Corica soborna (Hamilton, 1822) and Mystus bleekeri (Day, 1877). from the Ganges River (NW Bangladesh). Journal of Applied Ichthyology, 33: 661-662.
İlkyaz AT, Metin G, Soykan O, Kınacigil HT 2008. Length-Weight Relationship of 62 Fish Species from the Central Aegean Sea, Turkey. Journal of Applied Ichthyology, 24: 699-702.

İlkyaz AT, Metin G, Soykan O, Kınacıgil HT 2010. Age. Growth and Sexual Development of solenette, Buglossidium luteum (Risso, 1810), in the Central Aegean Sea. Journal of Applied Ichthyology, 26: 436-440.

İşmen A, Özen O, Altınağaç U, Özekinci U, Ayaz A 2007. Weight-Length Relationships of 63 Fish Species in Saros Bay. Turkey. Journal of Applied Ichthyology, 23: 707-708.

Kapiris K, Klaoudatos D 2011. Length-Weight Relationships for 21 Fish Species Caught in the Argolikos Gulf (central Aegean Sea. eastern Mediterranean). Turkish Journal of Zoology, 35: 717-723.

Kara A, Sağlam C, Acarlı D, Cengiz Ö 2017. LengthWeight Relationships for 48 Fish Species of the Gediz Estuary, in İzmir Bay (Central Aegean Sea, Turkey). Journal of the Marine Biological Association of the United Kingdom, 1-6.

Karakulak FS. Erk H. Bilgin B 2006. Length-Weight Relationships for 47 Coastal Fish Species from the Northern Aegean Sea. Turkey. Journal of Applied Ichthyology, 22: 274-278.

Kasapoğlu N, Düzgüneş E 2014. Length-Weight Relationships of Marine Species Caught by Five Gears from the Black Sea. Mediterranean Marine Science, 15: 95-100.

Keskin Ç, Gaygusuz Ö 2010. Length-Weight Relationships of Fishes in Shallow Waters of Erdek Bay (Sea of Marmara, Turkey). IUFS Journal of Biology, 69(2):87-94.

Kınacigil HT, Akyol O 2001. Effects on Trawl Selectivity of Growth and Reproduction in Diplodus annularis L. of Izmir Bay (Aegean Sea). Archive of Fisheries and Marine Research, 49(1):19-26.

Mater S, Kaya M. Bilecenoğlu M 2009. Marine Fishes of Turkey (4th press). Ege University Fisheries Faculty Publishings. No. 68. İzmir (In Turkish).

Moutopoulos DK, Stergiou KI 2002. Length-Weight and Length-Length Relationships of Fish Species from the Aegean Sea (Greece). Journal of Applied Ichthyology, 18: 200-203.

Navarro MR, Villamor B, Myklevoll S, Gil J, Abaunza P, Canoura J 2012. Maximum Size of Atlantic mackerel (Scomber scombrus) and Atlantic chub mackerel (Scomber colias) in the Northeast Atlantic. Cybium, 36: 406-408.

Özaydın O, Bilecenoğlu M, Kaya M 2000. Age and Growth of the Curled Picarel Centracanthus cirrus Rafinesque. 1810 (Osteichthyes: Centracanthidae) in Northern Cyprus. Eastern Mediterranean Sea. Acta Adriatica, 41: 35-42.

Özaydın O, Taskavak E 2006. Length-Weight Relationships for 47 Fish Species From Izmir Bay 
(eastern Aegean Sea, Turkey). Acta Adriatica, 47: 211-216.

Özaydın O, Uçkun D, Akalın S, Leblebici S, Tosunoğlu Z 2007. Length-Weight Relationships of Fishes Captured from Izmir Bay, Central Aegean Sea. Journal of Applied Ichthyology, 23: 695-696.

Özekinci U, Cengiz Ö, İşmen A, Altınağaç U, Ayaz A 2009. Length-Weight Relationships of Thirteen Flatfishes (Pisces: Pleuronectiformes) from Saroz Bay (North Aegean Sea. Turkey). Journal Animal and Veterinary Advences, 8: 1800-1801.

Petrakis D, Stergiou KI 1995. Weight-Length Relationships for 33 Fish Species in Greek waters. Fisheries Research, 21: 465-469.

Richter H, Lückstädt C, Focken U, Becker K 2000. An Improved Procedure to Assess Fish Condition on the Basis of Length-Weight Relationships. Archive of Fishery and Marine Research, 48: 255-264.

Ricker WE 1975. Computation and Interpretation of Biological Statistics of Fish Populations. Journal of the Fisheries Research Board of Canada, 191: 1382.

Safran P 1992. Theoretical Analysis of the WeightLength Relationships in Fish Juveniles. Marine
Biology, 112: 545-551.

Sangun L, Akamca E, Akar M. 2007. Weight-Length Relationships for 39 Fish Species from the NorthEastern Mediterranean Coast of Turkey. Turkish Journal of Fisheries and Aquatic Sciences, 7: 37-40.

Tokat E, Sayın E 2007. Water Masses Influencing the Hydrographic Properties of Saros Bay. Rapp Comm Int Mer Medit, 38: 205.

Torres MA, Ramos F, Sobrino I 2012. Length-Weight Relationships of 76 Fish Species from the Gulf of Cadiz (SW Spain). Fisheries Research, 127: 171175.

Tosunoğlu Z, Akyol O, Metin G, Tokaç A, Ünsal S. 1997. Gülbahçe Körfezi'ndeki Üç Sparid Türünün Populasyon Özelliklerinin Araştırılması. Ege Journal of Fisheries and Aquatic Sciences, 14(1-2): 127-143.

Verdiell-Cubedo D, Oliva-Paterna FJ, Torralva M 2006. Length-Weight Relationships for 22 Fish Species of the Mar Menor Coastal Lagoon (western Mediterranean Sea). Journal of Applied Ichthyology, 22: 293-294.

Wootton RJ 1998. Ecology of Teleost Fishes. 2nd Edition. Kluwer Academic. London. 